\title{
ANALISIS SPASIAL PENYAKIT DERMATITIS DI PUSKESMAS LABAKKANG KABUPATEN PANGKEP
}

\author{
SPATIAL ANALYSIS OF DERMATITIC DISEASE \\ IN PUSKESMAS LABAKKANG PANGKEP DISTRICT
}

\author{
Andi Shaleha Maudani ${ }^{1 *}$,Muh.Ikhtiar ${ }^{2}$, Alfina Baharuddin ${ }^{2}$ \\ ${ }^{1}$ Program Studi Magister Kesehatan Masyarakat, Program Pasca Sarjana \\ Universitas Muslim Indonesia \\ ${ }^{2}$ Departemen Kesehatan Lingkungan, Program Pasca Sarjana \\ Universitas Muslim Indonesia \\ *email: shalehaandi.maudani@gmail.com ${ }^{1}$
}

\begin{abstract}
Dermatitis is inflammation of the skin that causes clinical abnormalities in the form of polymorphic collections and complaints of itching with a prevalence of cases in the world as much as 10\%. The number of cases of dematitis in Indonesia is still high, especially in Pangkep Regency with 23,583 patients in 2017 and 10,436 patients in 2018. The purpose of this study was to analyze and map dermatitis in the working area of Labakkang Puskesmas in Pangkep Regency. This research is a quantitative observational study. The sample of this study was 284 respondents who were selected using simple random sampling technique. Data analysis using ArcGIS. The results of this study were 195 (65\%) Good PHBS Patients with 102 (35\%), 73 (25\%) History of Skin Disease with 224 (75\%) history, 73 (32\%) History of Allergy does not have a history of 201 (67\%), contact time that has never experienced 124 (42\%), not as long as 151 (51\%) and as many as 22 (7\%), Eligible Temperature as much as 128 (43\%), Not eligible as many as 169 (57\%), Humidity fulfills the requirements of 247 (83\%), and does not meet the requirements of 169 (17\%). So it can be concluded that the incidence of dermatitis in Pangkep Regency mostly occurs in the elderly age group with poor personal hygiene and long exposure time to chemicals.
\end{abstract}

Keywords: Dermatitis, Contact Duration, ArcGIS, skin disease

\begin{abstract}
Abstrak
Dermatitis adalah peradangan kulit yang menyebabkan kelainan klinis dalam bentuk pengkoleran polimorfik dan keluhan gatal dengan prevalensi kasus di duni sebanyak $10 \%$. Angka kasus dematitis di Indonesia masih tinggi, khususnya di Kabupaten Pangkep dengan 23.583 pasien pada tahun 2017 dan 10.436 pasien pada tahun 2018. Tujuan penelitian ini untuk menganalisis dan memetakan dermatitis di wilayah kerja Puskesmas Labakkang di Kabupaten Pangkep. Penelitian ini adalah penelitian observasional kuantitatif. Sampel penelitian ini adalah 284 responden yang dipilih menggunakan teknik simple random sampling. Analisis data menggunakan ArcGIS. Hasil penelitian ini adalah 195 (65\%) Pasien PHBS yang Baik dengan 102 (35\%), 73 (25\%) Riwayat Penyakit Kulit dengan 224 (75\%) riwayat, 73 (32\%) Riwayat Alergi tidak memiliki sejarah 201 (67\%), waktu kontak yang belum pernah mengalami 124 (42\%), tidak selama 151 (51\%) dan sebanyak 22 (7\%), Suhu yang Memenuhi Syarat sebanyak 128 (43\%) ,Tidak memenuhi syarat sebanyak 169 (57\%), Kelembaban yang memenuhi persyaratan 247 (83\%), dan tidak memenuhi persyaratan 169 (17\%). Sehingga dapat disimpulkan bahwa kejadian dermatitis di Kabupaten Pangkep banyak terjadi pada kelompok usia lansia dengan personal hygiene yang buruk dan waktu paparan bahan kimia yang lama.
\end{abstract}

Kata kunci: Dermatitis, Durasi Kontak, ArcGIS, penyakit kulit

PENDAHULUAN

Kondisi lingkungan dapat mempengaruhi kesehatan masyarakat seperti kejadian dermatitis. Banyak aspek kesejahteraan manusia yang dipengaruhi oleh kondisi lingkungan. Selain itu juga 
banyak penyakit dapat timbul karena didukung dan dirangsang oleh faktor lingkungan. Pada hakikatnya, kesehatan adalah keadaan sejahtera dari badan, jiwa, dan sosial yang memungkinkan setiap orang hidup produktif secara sosial ekonomi. Oleh karena itu, jika dikaji lebih lanjut maka dapat disadari bahwa tidak banyak manusia di muka bumi ini yang berada dalam kondisi sehat sempurna. Akan tetapi, hal ini bukan berarti semua manusia selalu menderita penyakit karena arti penyakit sendiri merupakan suatu perubahan yang terjadi pada tubuh manusia sebagai respon dari faktor lingkungan yang mungkin berupa nutrisi, kimia, biologi atau psikologi (Gerry, 2010).

Dermatitis Atopik (DA) merupakan salah satu masalah kesehatan global jika dilihat dari peningkatan prevalensi dan biaya untuk pengobatannya yang tinggi. Prevalensi Dermatitis Atopik meningkat dua sampai tiga kali lipat di negara industri selama tiga dekade terakhir yaitu $15-30 \%$ pada anak dan $2-10 \%$ pada dewasa. Data terbaru menunjukkan bahwa Dermatitis Atopik merupakan masalah utama di negara berkembang. Sekitar $85 \%$ pasien dengan Dermatitis Atopik adalah anak usia dini, dan $70 \%$ dari pasien dermatitis atopik berlanjut menjadi asma atau rhinitis alergi (Noviyanti, dkk. 2015). Selanjutnya hampir 50\% penduduk di dunia mengalami jamur kulit seperti panu terutama di daerah tropis yang beriklim panas dan lembap. di Indonesia Angka insiden dermatofitosis sejak tahun 1998 yang tercatat melalui Rumah Sakit Pendidikan Kedokteran di Indonesia sangat bervariasi, dimulai dari persentase terendah sebesar 4,8\% (Surabaya) hingga persentase tertinggi sebesar 82,6 \% (Surakarta) dari seluruh kasus dermatomycosis (Cahyawati, dkk., 2011). Sebanyak 14 provinsi mempunyai prevalensi dermatitis diatas prevalensi nasional, yaitu Nanggroe Aceh Darussalam, Sumatera Barat, Bengkulu, Bangka Belitung, DKI Jakarta, Jawa Barat, Jawa Tengah, DI Yogyakarta, Nusa Tenggara Timur, Kalimantan Tengah, Kalimantan Selatan, Sulawesi Utara, Sulawesi Tengah, dan Gorontalo (Lestari, dkk., 2007).

Sementara itu, data Dinas Kesehatan Kabupaten Pangkep tahun 2017 menunjukkan bahwa penyakit dermatitis berada pada urutan ketiga dari 10 penyakit tertinggi di Puskesmas dengan jumlah penderita sebanyak 23.583. Di tahun 2018 penyakit dermatitis berada pada urutan kedelapan dari 10 penyakit tertinggi dengan jumlah penderita sebanyak 10.436 . Berdasarkan hal tersebut dapat disimpulkan bahwa kejadian penyakit dermatitis masih terjadi di tengah masyarakat, khususnya Kabupaten Pangkep. Penelitian ini bertujuan untuk menganalisis penyebaran kejadian penyakit dermatitis di wilayah kerja Puskesmas Labakkang, Kabupaten Pangkep dalam upaya mendukung kegiatan pencegahan terjadinya penyakit dermatitis di masyarakat.

\section{METODE PENELITIAN}

Penelitian ini merupakan penelitian observasional dengan rancang bangun cross sectional. Teknik pengumpulan data menggunakan pendekatan Geographic Information Sistem (GIS) yang dilaksanakan di seluruh wilayah kerja Puskesmas Labakkang, Kabupaten Pangkep pada Bulan Agustus - Oktober Tahun 2019. Responden adalah seluruh penderita penyakit dermatitis tahun 2019 di Puskesmas Labakkang, Kabupaten Pangkep sebanyak 974 penderita. Besar sampel yang digunakan sebanyak 297 orang berdasarkan hasil perhitungan rumus slovin. Pemilihan sampel dilakukan secara acak menggunakan simple random sampling. Instrumen penelitian ini yaitu lembar observasi, thermo-hygrometer, Global Positioning System (GPS), map source, Arcgis, dan Google Earth. GPS yang digunakan untuk memetakan kondisi wilayah di sekitar rumah sampel sedangkan map source, ArcGis, dan Google Earth untuk memetakan hasilnya.

\section{HASIL DAN PEMBAHASAN}

Dermatitis adalah peradangan kulit yang ditandai oleh rasa gatal, dapat berupa penebalan/bintil kemerahan, multipel mengelompok atau tersebar, kadang bersisik, berair dan lainnya. Pembentukan lepuh atau gelembung kecil pada kulit hingga akhirnya pecah dan mengeluarkan cairan. Istilah eksim juga digunakan untuk sekelompok kondisi yang menyebabkan perubahan pola pada kulit dan menimbulkan perubahan spesifik di bagian permukaan. Istilah ini diambil dari Bahasa Yunani yang berarti 
mendidih atau mengalir keluar. Akibat permukaan kulit terkena bahan atau unsurunsur yang ada di lingkungannya (faktor eksogen). Namun demikian, untuk terjadinya suatu jenis dermatitis atau beratnya gejala dermatitis, kadang-kadang dipengaruhi pula oleh faktor kerentanan kulit seseorang (faktor endogen) Widiyanto, dkk (2014).

\section{Jenis Dermatitis}

Distribusi penderita dermatitis berdasarkan jenis kelamin responden di wilayah kerja Puskesmas Labakkang tahun 2019 disajikan oleh Tabel 1. Berdasarkan tabel 1 dapat diketahui bahwa jenis dermatitis responden tertinggi adalah jenis dermatitis kontak alergi sebanyak 158 orang
(53.2\%) dan terendah adalah jenis dermatitis seborik sebanyak masing-masing 10 orang (3.4\%). Sedangkan distribusi spasial kejadian dermatitis berdasarkan jenis dermatitis penderita dermatitis di wilayah kerja Puskesmas Labakkang Kabupaten Pangkep Tahun 2019 dapat dilihat pada Gambar 1.

Berdasarkan Gambar 1 diketahui bahwa jenis dermatitis paling banyak jenis dermatitis kontak alergi tersebar disemua wilayah kerja Puskesmas Labakkang dan di Kelurahan Labakkang paling banyak penderita dermatitis jenis dermatitis alergi sedangkan bahwa jenis dermatitis paling sedikit jenis dermatitis seboroik tersebar disemua wilayah kerja Puskesmas Labakkang.

Tabel 1. Distribusi Penderita Dermatitis Berdasarkan Jenis Dermatitis Di Wilayah Kerja Puskesmas Labakkang Kab. Pangkep Tahun 2019

\begin{tabular}{|c|c|c|c|c|c|c|}
\hline \multirow{2}{*}{$\begin{array}{c}\text { Jenis } \\
\text { Dermatitis }\end{array}$} & \multicolumn{4}{|c|}{ Desa/Kelurahan } & \multirow{2}{*}{$\mathrm{n}$} & \multirow{2}{*}{$\%$} \\
\hline & Gentung & Kanaungan & Labakkang & Mangallekana & & \\
\hline Kontak Alergi & 17 & 31 & 64 & 46 & 158 & 53,2 \\
\hline Numularis & 10 & 11 & 15 & 23 & 59 & 19,9 \\
\hline Kontak Iritan & 1 & 6 & 8 & 10 & 25 & 8,4 \\
\hline Atopik & 4 & 2 & 8 & 9 & 23 & 7,7 \\
\hline Neurodermatitis & 2 & 4 & 7 & 9 & 22 & 7,4 \\
\hline Seboroik & 2 & 2 & 3 & 3 & 10 & 3,4 \\
\hline
\end{tabular}

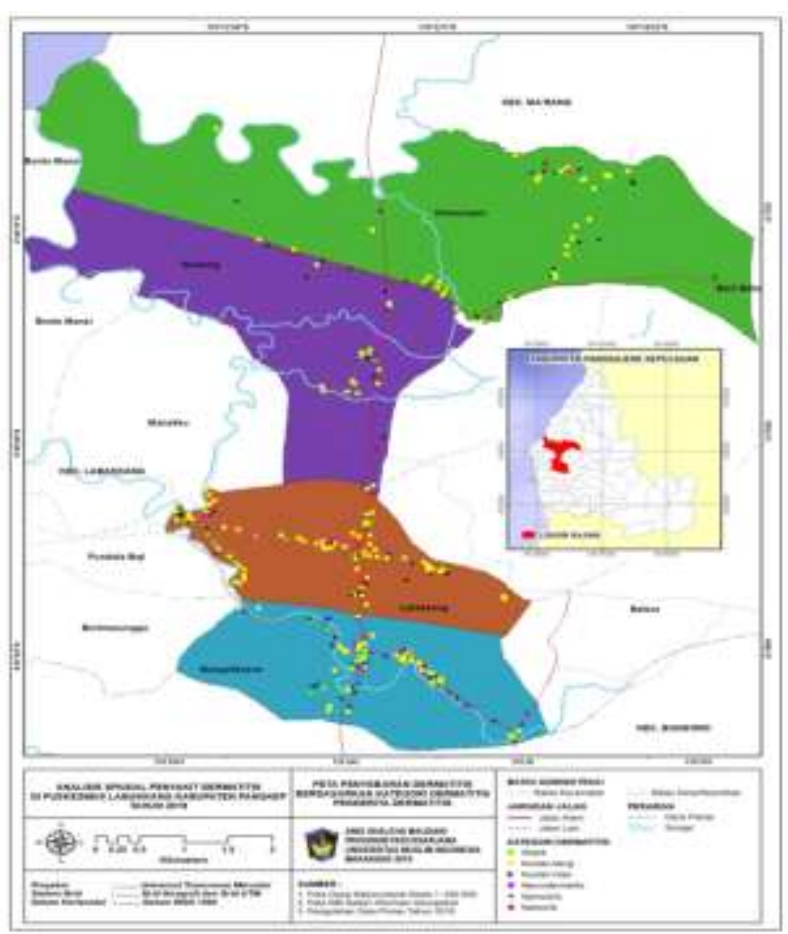

Gambar 1. Peta Penyebaran Dermatitis Berdasarkan Jenis Dermatitis Di Wilayah Kerja Puskesmas Labakkang Kab. Pangkep Tahun 2019

Analisis spasial penyebaran penyakit dermatitis di wilayah kerja Puskesmas Labakkang berdasarkan jenis dermatitis dapat dilihat pada Gambar 1 menunjukkan bahwa jenis dermatitis tertinggi adalah jenis dermatitis kontak alergi sebanyak 158 orang (53.2\%) paling banyak di Kelurahan Labakkang. Diketahui bahwa dermatitis kontak alergi muncul saat kulit bersentuhan dengan zat allergen yang memicu sistem kekebalan tubuh beraksi, menyebabkan kulit gatal dan meradang. Zat alergen yang sering memicu reaksi alergi pada kulit diantaranya adalah obat-obatan (misalnya krim antibiotic), zat yang ada di udara (misalnya serbuk sari), tanaman, bahan logam dalam perhiasan, dan bahan kosmetik.

Kemudian dermatitis Numularis sebanyak 59 orang (19.9) paling banyak di Kelurahan Mangallekana. Beberapa faktor yang meningkatkan risiko seseorang terkena dermatitis numularis adalah kulit yang sangat kering, menderita atau memiliki riwayat dermatitis, aliran darah yang kurang baik dan pembengkakan di kaki, cedera pada kulit akibat gigitan serangga, infeksi kulit oleh bakteri, hidup dan tinggal di daerah 
yang kering atau dingin.

Dermatitis kontak iritan 25 orang (8.4\%) paling banyak di Kelurahan Mangallekana. Jenis dermatitis ini terjadi kontak langsung lapisan luar kulit dengan zat tertentu, sehingga merusak lapisan pelindung kulit. Beberapa zat yang dapat memicu dermatitis kontak iritan adalah sabun, tetergen, sampo, cairan pemutih, zat yang berada di udara (misalnya serbuk gergaji atau serbuk wol), tumbuhan, pupuk, pestisida, farfum dan bahan pengawet.

Penderita Dermatitis atopic sebanyak 23 orang $(7.7 \%)$ paling banyak di Kelurahan Mangallekana dan cenderung yang menderita dermatitis atopik kategori umur balita, gejala dermatitis atopik sering memiliki pemicu tertentu dari bahan iritan seperti sabun dan detegen, faktor lingkungan seperti cuaca dingin dan kering, kelembaban, dan hal paling spesifik seperti tungau debu rumah dan bulu hewan peliharaan, alergi makanan seperti alaergi susu sapi, telur, kacang tanah, kedelai atau gandum.

Penderita Neurodermatitis 22 orang (7.4\%) paling banyak di Kelurahan Mangallekana. Jenis dermatitis ini terjadi pada kategori umur dewasa karena pemicu rasa gatal pada kasus neorodermatitis adalah cedera pada saraf, kulit kering, keringat, cuaca panas dan aliran darah kurang baik, gangguan kecemasan seperti stress dan rasa tertekan dalam jangka panjang.

Dermatitis seborik sebanyak 10 orang (3.4\%) jenis dermatitis seboroik yang paling sering terkena yaitu kulit kepala, bulu mata, alis, sisi hidung dan bagian tubuh lain yang berminyak. Dilansir dari American Academy of Dermatology gejala dermatitis seboroik terbagi dua yaitu pada orang dewasa dan bayi. Pada orang dewasa ditandai dengan bercak bersisik pada kulit, bercak terlihat lembab dan berminyak, sisik mengelupas, rasa gatal terutama pada kulit kepala. Sementara pada bayi bercak kuning bersisik dan berminyak pada kulit kepala, lapisan sisik yang tebal dan menutupi seluruh kepala.

\section{Kejadian Dermatitis Berdasarkan Umur}

Berdasarkan Tabel 2 tingkat kategori umur tertinggi adalah usia lanjut (40 - 50 tahun) sebanyak 127 orang (42.8\%) dan kategori umur terendah adalah anak-anak (6 - 11 tahun) sebanyak 29 orang (9.8\%). Distribusi spasial kejadian dermatitis berdasarkan umur penderita dermatitis di wilayah kerja Puskesmas Labakkang Kabupaten Pangkep Tahun 2019 tersebar semua kategori umur dari balita, anak-anak, remaja, dewasa, dan lansia.

Penderita dermatitis dari ketegori usia lanjut dan tersebar di semua wilayah kerja Puskesmas Labakkang dan paling banyak penderita dermatitis yaitu kategori usia lanjut yang terdapat di Kelurahan Mangallekana sedangkan untuk penderita paling sedikit yaitu kategori anak yang tersebar di kelurahan Kanaungan, penyebarannya dapat di lihat pada Gambar 2.

Tabel 2. Distribusi Responden Penderita Dermatitis Berdasarkan Umur di Wilayah Kerja Puskesmas Labakkang Kab. Pangkep Tahun 2019

\begin{tabular}{ccccccc}
\hline Kategori & \multicolumn{9}{c}{ Desa/Kelurahan } & \multirow{2}{*}{ N } & $\%$ \\
\cline { 2 - 5 } Umur & Gentung & Kanaungan & Labakkang & Mangallekana & & 13 \\
\hline $0-5$ & 3 & 3 & 17 & 13 & 36 & 12,1 \\
$6-11$ & 6 & 3 & 9 & 11 & 29 & 9,8 \\
$12-25$ & 6 & 4 & 23 & 7 & 40 & 13,5 \\
$26-40$ & 7 & 8 & 21 & 29 & 65 & 21,9 \\
$40-60$ & 14 & 38 & 35 & 40 & 127 & 42,8 \\
\hline
\end{tabular}

Berdasarkan umur responden, tingkat kategori umur tertinggi penderita dermatitis adalah kategori usia lanjut (40 - 60 tahun) sebanyak 127 orang $(42.8 \%)$ dapat dilihat pada gambar 2 penderita usia lanjut yang paling banyak tersebar di Kelurahan Manggalekana. Banyaknya responden yang mengalami dermatitis pada kelompok usia ini karena kelompok ini tergolong lebih mudah rentan terhadap berbagai rangsangan dari bahan pencemar yang dapat menginfeksi kulit. Hal ini disebabkan karena kulit responden akan mengalami degenerasi seiring bertambahnya usia yaitu terjadinya penipisan dan hilangnya lapisan lemak pada kulit sehingga kulit menjadi kering. Dengan demikian seorang yang sudah tua akan rentan terhadap bahan-bahan alergen dan 
iritan seperti sabun dan deterjen.

$\mathrm{Hal}$ ini sesuai dengan pendapat dari Cohen dan Jacob (2008) yang menyatakan bahwa kulit manusia mengalami degenerasi seiring bertambahnya usia, sehingga menyebabkan penipisan pada lapisan lemak dibawah kulit akibatnya kulit menjadi lebih kering dan mudah teriritasi menjadi dermatitis kontak. Menurut Achmadi (2011), dampak kesehatan juga tergantung umur, semakin muda semakin rentan, semakin tua juga semakin rentan. Menurut Sucipta (2008) dalam Norma, dkk (2017) dalam penelitiannya mengemukakan bahwa dermatitis dapat diderita oleh semua orang dari golongan umur. Seorang yang lebih tua memiliki kulit kering dan tipis yang tidak toleran terhadap sabun dan pelarut. Sedangkan penelitian ini tidak sejalan dengan penelitian yang dilakukan oleh Suryani (2011) dalam Ersani (2012) yang dilakukan pada karyawan di pabrik kosmetik PT. Cosmar Indonesia menunjukkan hasil menunjukan bahwa rata-rata usia pekerja yang mengalami dermatitis kontak yaitu 23 tahun yang mana masih tergolong dalam usia muda.

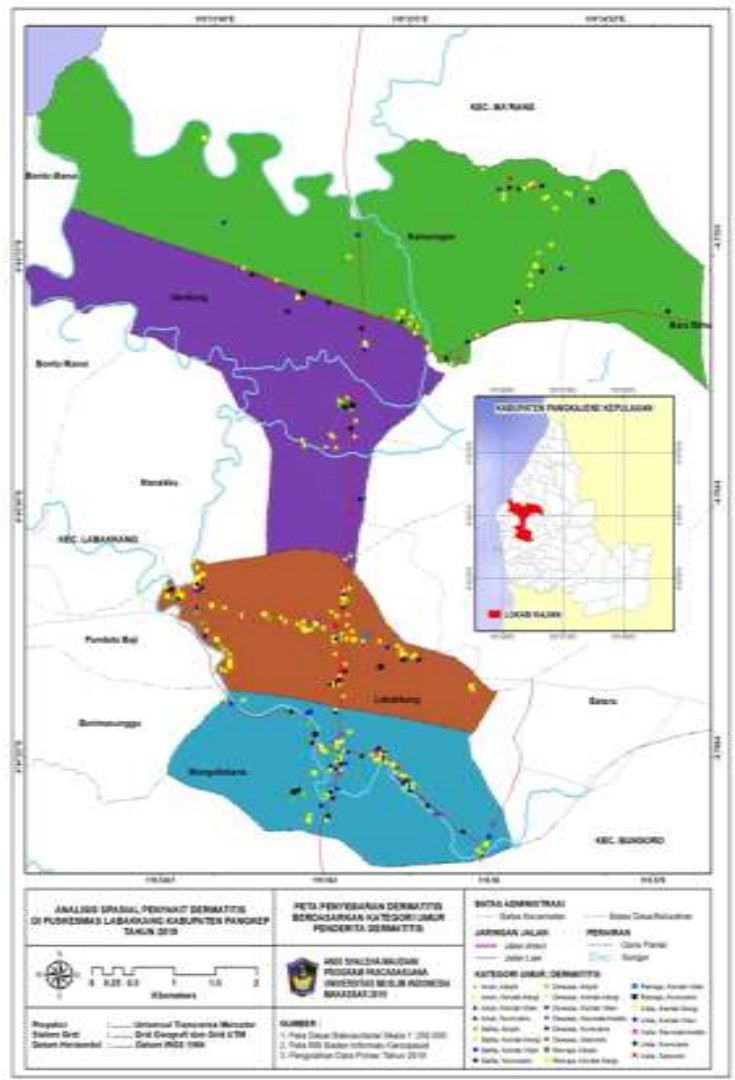

Gambar 2. Peta Penyebaran Dermatitis Berdasarkan Umur di Wilayah Puskesmas Labakkang Kab. Pangkep Tahun 2019

\section{Kejadian Dermatitis Berdasarkan Personal Hygiene}

Tabel 3 menunjukkan bahwa dari 297 responden terdapat $64.3 \%$ yang memiliki personal hygiene yang baik dan $35.7 \%$ yang memiliki personal hygiene yang tidak baik. Distribusi spasial kejadian dermatitis berdasarkan personal hygiene penderita dermatitis di wilayah kerja Puskesmas Labakkang Kabupaten Pangkep Tahun 2019 dapat dilihat pada Gambar 3.

Berdasarkan Gambar 3 diketahui bahwa personal hygiene penderita dermatitis yang baik tersebar disemua wilayah kerja Puskesmas Labakkang dan di Kelutahan Labakkang yang paling banyak memiliki personal hygiene yang baik sedangkan di Desa Kanaungan paling banyak memiliki personal hygiene yang tidak baik.

Distribusi spasial kejadian dermatitis berdasarkan personal hygiene penderita dermatitis di wilayah kerja Puskesmas Labakkang Kabupaten Pangkep Tahun 2019 dari Gambar 3 diketahui bahwa personal hygiene penderita dermatitis yang baik tersebar disemua wilayah kerja Puskesmas Labakkang dan di Kelutahan Labakkang yang paling banyak memiliki personal hygiene yang baik sedangkan di Desa Kanaungan paling banyak memiliki personal hygiene yang tidak baik.

Personal hygiene merupakan satu tindakan dalam memelihara kesehatan diri serta merupakan salah satu faktor yang dapat mencegah dari terjadinya dermatitis. Personal hygiene yang dinilai adalah tingkat pengetahuan responden yang meliputi kebersihan kulit, kebersihan tangan dan kuku, kebersihan pakaian, kebersihan handuk serta kebersihan tempat tidur dan sprei dengan kejadian dermatitis kemudian dapat dibagikan menjadi 2 kategori yaitu kategori baik dan kategori tidak baik.

Berdasarkan hasil penelitian, didapatkan bahwa tingkat pengetahuan responden tentang personal hygiene yang meliputi kebersihan kebersihan kulit, kebersihan tangan dan kuku, kebersihan pakaian, kebersihan handuk dan kebersihan tempat tidur dan sprei dari 297 responden terdapat 191 orang $(64.3 \%)$ yang memiliki personal hygiene yang baik dan 106 orang $(35.7 \%)$ yang memiliki personal hygiene yang tidak baik. 
Tabel 3. Penderita Dermatitis Berdasarkan Personal Hygiene di Wilayah Kerja Puskesmas Labakkang Kab. Pangkep Tahun 2019

\begin{tabular}{ccccccc}
\hline Personal & \multicolumn{5}{c}{ Desa/Kelurahan } & \multirow{2}{*}{$\%$} \\
\cline { 2 - 5 } Hygiene & Gentung & Kanaungan & Labakkang & Mangallekana & & \\
\hline Baik & 21 & 25 & 80 & 65 & 191 & 64,3 \\
Tidak Baik & 15 & 31 & 25 & 35 & 106 & 35,7 \\
\hline
\end{tabular}

Dalam mencuci tangan lebih baik jika disertai dengan menggunakan sabun serta membersihkan sela jari tangan dan kaki dengan air mengalir. Dengan mandi dan mengganti pakaian setelah bekerja akan mengurangi kontak dengan mikroorganisme yang hidup di permukaan kulit yang berasal dari lingkungan sekitar kita. Kulit akan terhindar dari berbagai penyakit jika dijaga dengan baik seperti dengan mencuci tangan dan kaki, mandi dan ganti pakaian secara rutin dapat terhindar dari penyakit kulit.

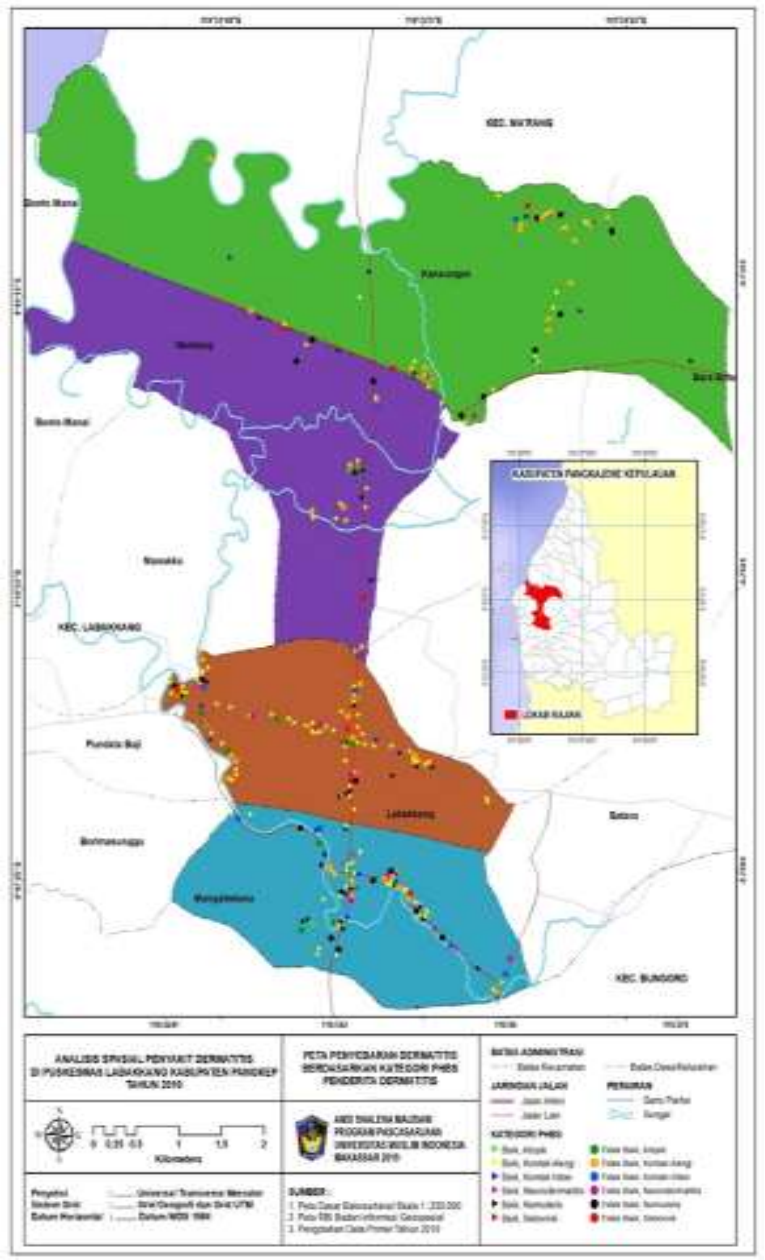

Gambar 3. Distribusi Responden

Berdasarkan Personal Hygiene di Wilayah

Kerja Puskesmas Labakkang Kab. Pangkep

Hasil penelitian Nooryasni (2013) semakin buruknya pengetahuan personal hygiene seseorang itu, semakin rentang dia menderita dermatitis atopik. Hal ini dikarenakan dari hasil penelitian didapatkan bahwa personal hygiene yang meliputi kebersihan kulit didapatkan bahwa 68,1\% menderita dermatitis atopik dengan pengetahuan kebersihan kulit yang buruk. Hal ini juga sejalan dengan pendapat Notoatmodjo (2007) yang menyatakan bahwa pengetahuan tentang personal hygiene sangat penting, karena pengetahuan yang baik dapat meningkatkan kesehatan dan dapat mencegah agar terhindar dari kondisi atau keadaan sakit.

\section{Lama Kontak Penyakit Dermatitis}

Berdasarkan Tabel 4 dari 297 responden terdapat 22 orang $(7.4 \%)$ yang lama kontak dengan bahan kimia, 151 orang (50.8\%) yang tidak lama kontak dengan bahan kimia dan 124 orang (41.8\%) yang tidak pernah kontak dengan bahan kimia. Distribusi spasial kejadian dermatitis berdasarkan lama kontak penderita dermatitis di wilayah kerja Puskesmas Labakkang Kabupaten Pangkep Tahun 2019 dapat dilihat pada Gambar 5.

Distribusi spasial kejadian dermatitis berdasarkan lama kontak penderita dermatitis di wilayah kerja Puskesmas Labakkang Kabupaten Pangkep Tahun 2019 dari Gambar 5 diketahui bahwa di Desa Kanaungan paling banyak yang lama terkena dengan bahan kimia, di Kelurahan Labakkang yang paling banyak tidak lama terkena bahan kimia sedangkan di Kelurahan Mangallekana paling banyak yang tidak pernah terkena bahan kimia dalam sehari.

Lama kontak adalah jangka waktu responden berkontak dengan bahan alargen dan bahan iritan dalam hitungan jam/hari. Setiap responden memiliki lama kontak yang berbeda-beda sesuai dengan proses aktifitas sehari-hari. Semakin lama berkontak dengan bahan alargen dan bahan iritan maka peradangan atau iritasi kulit dapat terjadi sehingga menimbulkan kelainan kulit (Lestari dan Ira, 2008). Menurut Djuanda dan Sularsito (2003) yang pada hasil penelitiaannya bahwa lama 
kontak dengan bahan alargen dan bahan iritan yang terjadi akan meningkatkan terjadinya dermatitis kontak akibat kerja. Responden yang berkontak dengan bahan alargen dan bahan iritan menyebabkan kerusakan sel kulit lapisan luar, semakin lama berkontak dengan bahan alargen dan bahan iritan maka akan semakin merusak sel kulit lapisan yang lebih dalam dan memudahkan untuk terjadinya dermatitis. Bahan alergen yang sering memicu reaksi alergi pada kulit diantaranya adalah obatobatan (misalnya krim antibiotic), zat yang ada di udara (misalnya serbuk sari), tanaman, bahan logam dalam perhiasan, dan bahan kosmetik. Sedangkan bahan iritan yang dapat memicu dermatitis kontak iritan adalah sabun, tetergen, sampo, cairan pemutih, zat yang berada di udara (misalnya serbuk gergaji atau serbuk wol), tumbuhan, pupuk, pestisida, farfum dan bahan pengawet.

Tabel 4. Distribusi Responden Berdasarkan Lama Kontak Di Wilayah Kerja Puskesmas Labakkang Kab. Pangkep Tahun 2019

\begin{tabular}{|c|c|c|c|c|c|c|}
\hline \multirow{2}{*}{$\begin{array}{c}\text { Lama } \\
\text { Kontak }\end{array}$} & \multicolumn{4}{|c|}{ Desa/Kelurahan } & \multirow{2}{*}{$\mathrm{n}$} & \multirow{2}{*}{$\%$} \\
\hline & Gentung & Kanaungan & Labakkang & Mangallekana & & \\
\hline Lama & 4 & 7 & 6 & 5 & 22 & 7,4 \\
\hline Tidak Lama & 19 & 27 & 55 & 50 & 151 & 50,8 \\
\hline Tidak Pernah & 13 & 22 & 44 & 45 & 124 & 41,8 \\
\hline
\end{tabular}

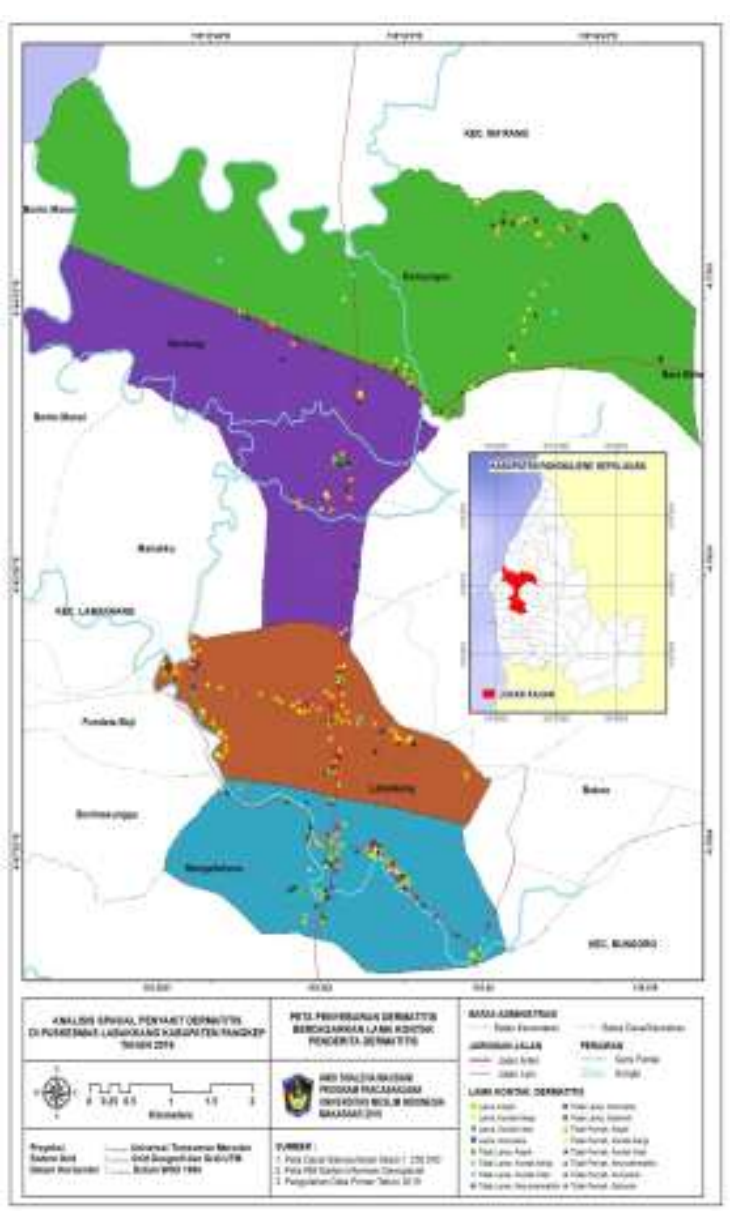

Gambar 4. Peta Penyebaran Dermatitis Berdasarkan Lama Kontak Di Wilayah Kerja Puskesmas Labakkang Kab. Pangkep Tahun 2019.

Hasil penelitian dari 297 responden terdapat 151 orang $(50.8 \%)$ yang tidak lama kontak dengan bahan alargen dan bahan iritan. Pada Gambar 4 dapat dilihat responden yang paling banyak lama kontak terhadap bahan alargen dan bahan iritan di Desa Kanaungan. Berdasarkan hasil penelitian diketahui responden yang mengalami dermatitis pada kelompok $\leq 7$ $\mathrm{jam} / \mathrm{hari}$. Hal ini dikarenakan masyarakat yang menggunakan bahan kimia untuk keperluan sehari-hari (mandi, cuci, kakus) memerlukan waktu $\leq 7 \mathrm{jam} / \mathrm{hari}$. Maka semakin kecil waktu seseorang terpapar dengan bahan iritan, maka peluang untuk mengalami dermatitis semakin kecil pula.

Hasil penelitian ini tidak sejalan dengan teori yang dikemukakan Retno dan Sularsito (2015) dalam Diansari (2017) menyatakan penyebab dermatitis adalah lama kontak dan kekerapan (terus menerus atau berselang) dengan bahan alergen. Menurut Achmadi (2011) menyatakan kebiasaan masyarakat mempengaruhi pajanan, oleh sebab itu lama kontak antara manusia dengan komponen lingkungan berpotensi tinggi terhadap bahaya penyakit, karena setiap orang memiliki lama kontak yang berbeda-berbeda tergantung perilakunya. Berdasarkan penelitian Nuraga, dkk (2008) dalam Noviyanti, dkk (2015), ada hubungan antara lama kontak dengan kejadian dermatitis kontak pada pekerja yang terpajan dengan bahan kimia di Perusahaan Industri Otomotif Kawasan Industri Cibitung Jawa Barat. Dalam penelitian tersebut didapatkan bahwa pekerja dengan lama kontak 8 jam/hari lebih banyak menderita dermatitis kontak dibanding dengan pekerja dengan lama kontak $<8$ jam/hari. 


\section{KESIMPULAN DAN SARAN}

\section{Kesimpulan}

Analisis spasil penyebaran penyakit dermatitis berdasarkan jenis dermatitisnya yang paling banyak ditemui yaitu jenis dermatitis kontak alergi terdapat di Kelurahan Labakkang dan terendah adalah dermatitis sebori. Berdasarkan umur banyak penderita dermatitis dari ketegori lansia dan aling sedikit terjadi pada anak. Personal hygiene responden di Kelurahan Labakkang yang lebih baik dibandingkan dengan responden di Desa Mangallekana. Sedangkan berdasarkan lama kontaknya, responden di Desa Kanaungan paling banyak terpapar bahan kimia dibandingkan responden di Kelurahan Labakkang dan Kelurahan Mangallekana.

\section{Saran}

Saran penelitian ini khususnya ditujukan kepada Puskesmas Labakkang terutama di bagian promosi kesehatan agar memberikan penyuluhan, sosialisasi, dan informasi kepada masyarakat terkait penyakit dermatitis dan pola hidup bersih dan sehat seiring dengan tingginya kasus penyakit dermatitis di wilayah kerja Puskesmas Labakkang.

\section{DAFTAR RUJUKAN}

1] Achmadi, U.F. 2011. Dasar-dasar Penyakit Berbasis Lingkungan. RajaGrafindo Persada, Jakarta

2] Cahyawati, Imma Nur dan Irwan Budiono. 2011. Faktor yang Berhubungan dengan Kejadian Dermatitis Pada Nelayan. Jurnal Kesehatan Masyarakat 6 (2) (2011) 134-141

3] Cohen, DE, Jacob SE. 2008. Allergic contact dermatitis, In: Fitzpatricks et al, editors, Dermatology in general medicine vol.1 7th ed. New York: McGraw Hill Medical;

4] Diansari, dkk. 2017. Analysis of Risk Factors Attenistic Dermatitis Attendance on The Center in Puskesmas Piah Padang. Jurnal Endurance STIKes Dharma Landbouw

\section{Padang}

5] Djuanda, S., dan Sularsito, S.A. 2003. Ilmu Penyakit Kulit Dan Kelamin. Balai Penerbit FKUI Yogyakarta: Gadjah Mada University Press, Jakarta

6] Ernasari. 2012. Pengaruh Penyuluhan Dermatitis Kontak Terhadap Pengetahuan Dan Sikap Perajin Tahu di Kelurahan Mabar Kecamatan Medan Deli Tahun 2011. Tesis: Fakultas Kesehatan Masyarakat USU

7] Gerry. 2010. Gambaran distribusi penderita penyakit Tinea imbrikata berdasarkan keadaan sosiodemografi dan klinis di desa Teluk Pongkal kecamatan Sokan kabupaten Melawi provinsi Kalimantan Barat tahun 2010. Jurnal kesehatan. Diunduh dari: http://jurnal.untan.ac.id/3967/ [diakses 30 Juli 2019]

8] Lestari, Fatma dan Hari Suryo Utomo. 2007. Faktor-faktor yang Berhubungan dengan Dermatitis Kontak Pada Pekerja di PT. Inti Pantja Press Industri. Jurnal: Makara Kesehatan Vol. 11 No.2 Desember 2007 : 61-68

9] Lestari, Ira, C. 2008. Penyakit Kulit Akibat Kerja. http://somelus.wordpress.com/2008/11/ 26/penyakit-kulit-akibat-kerja/. diakses 5 Agustus 2019

10] Muchlis, N. 2013. Karakteristik Penderita Dermatitis Pada Masyarakat di Puskesmas Tamangapa Kecamatan Manggala Kota Makassar. Skripsi. Fakultas Kesehatan Masyarakat Universitas Hasanuddin.

11] Norma dkk. 2017. Perbandingan Faktor Risiko Kejadian Dermatitis Kontak Iritan Antara Petani Garam Dan Petani Sawah Di Kacamatan Kaliori Kabupaten Rembang. Jurnal Kesehatan Masyarakat.

12] Noviyanti dkk. 2015. Faktor Resiko Pada Dermatitis Atopik. Jurnal Kedokteran Universita Sumatera.

13] Notoatmodjo, S. 2007. Kesehatan Masyarakat Ilmu dan Seni. Jakarta: Rineka Cipta. 